The Social Sciences 14 (12): 392-398, 2019

ISSN: $1818-5800$

(C) Medwell Journals, 2019

\title{
The Implementation of Standard Operating Procedures and the Complaint Handling Service Quality of the Government Secretariat of Makassar City, Indonesia
}

\author{
Fahrisal Husain, Tahir Kasnawi, Muhammad Ramli and Muhammad Ardi \\ Department of Public Administration, Universitas Negeri Makassar, \\ Jalan Bonto Langkasa Kampus Gunung Sari, 90222 Makassar, Indonesia
}

\begin{abstract}
This research aims to examine the handling of public complaints and the implementation of standard operating procedure No. SOP-SDKM-HMS-02 dated 27th March, 2012 which have been applied by the complaint handling service unit of the Makassar government secretariat. Employing qualitative methodology, the research is a case study at service organization level in a natural context. Thus, it generates descriptive data, both spoken dan written data from the participants involved. The data were collected from documents and interviews with competent informants. The findings indicate that there are weaknesses of the implementation of the standard operating procedure, particularly in the coordination stage, follow-up stage and the stage of follow-up monitoring. The weaknesses also include the unavailability of case completion time or schedule and the poor coordination with complainants when cases are resolved. This has an implication for the low public contribution in submitting complaints.
\end{abstract}

Key words: Standard operating procedure, bureaucratic performance, service quality, public satisfaction, complaint handling, poor coordination

\section{INTRODUCTION}

In 2010, the total number of Indonesian government employees has reached 4.7 million (the Indonesian Civil Service Agency). This number includes temporary civil service (PTT) but excludes police and military personnels. Considering the Indonesian population which has reached 242 million, the ratio of civil servants to the population is still low, especially when compared to other countries such as Malaysia and Singapore. The recruitment of civil servants is generally done mechanistically. It is rarely implemented based on the actual need or assessment of the required number.

The public sector is characterized by monopoly in the provision of goods and services for public stakeholders for example services related to ID card, driving license, land certificate, passport and business permit. The general guideline of public satisfaction index includes such criteria as: simplicity, clarity, certainty and timeliness, accuracy, non-discriminatory, liable, completeness of facilities and infrastructure, ease of access, honesty, rigor, discipline, courtesy, friendliness, comfort and safety.

The Indonesian bureaucracy is characterized with intransparency, institutions which lack of funding, unskilled workers and structured corruptions. The bureaucracy does not reflect the concept of public service it indicates low administration quality (Synnerstrom,
2007). The low capacity of civil servants significantly affects education, foreign investment, health, infrastructures and manufacturing (Kennedy, 2010). The performance of poor areas in Indonesia is an indicator of the low service quality of the government. People often have to pay illegal fees to obtain certain services.

The low productivity of civil servants, especially in providing services for the public, corruption and nepotism in the administration of public services are indicated by a survey conducted by the Centre for Population Policy Studies, Gajah Mada University, Indonesia. The centre found that $80 \%$ of civil servants only use the implementation guide (juklak) and technical guide (juknis) which contain rigid rules not flexible. Thus, they lack of innovation in providing services. Only $16 \%$ of the civil servants are oriented to public satisfaction. The rest $4 \%$ refer to the organization's vision and mission in providing services for the public.

Public service privatization has emerged as an alternative solution in accordance with the new public management concept (Fountain, 1999). Public service reformation is implemented by conducting institution re-organization, simplifying procedures, implementing minimum service standards, improvement of the use of information technology and communication and the implementation of quality management system which includes public complaint management. Complaint management which has not run

Corresponding Author: Fahrisal Husain, Department of Public Administration, Universitas Negeri Makassar, Jalan Bonto Langkasa Kampus Gunung Sari, 90222 Makassar, Indonesia 
The Soc. Sci., 14 (11): 392-398, 2019

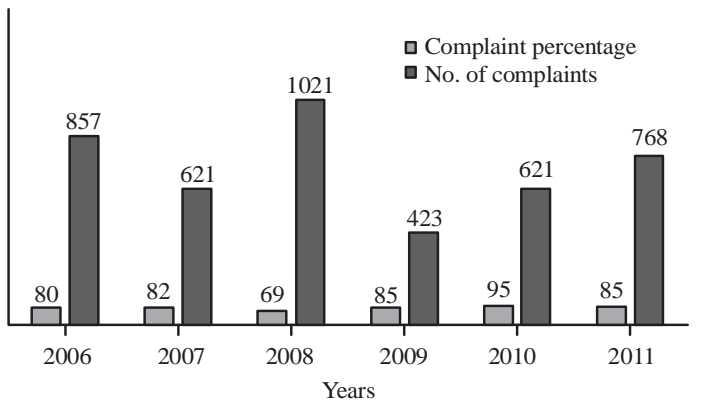

Fig. 1: Complaint settlement from 2006-2011; complaint handling unit, Makassar government secretariat

optimally results in public unawareness of their right to file complaints or feedback related to the public services they receive.

A study by Sudrajat reveals that $53.8 \%$ of the public use mass media as an effective medium for filing complaints related to services which they receive, followed by radio/television 33.91\% and SMS 30.65\%. The results of the integrity survey of the Indonesian Corruption Eradication Commission indicate that the quality of public services in Indonesia obtains the score of 6.84 in the scale of 10 for central institutions and 6.69 for regional institutions. The integrated score includes the tendency of bribery in the process, the implementation of standard operating procedure, the conformity of services and SOP, the openess of information, fairness and quickness in delivering services and easiness for the public in filing complaints related to particular services.

Almost all government institutions have standard operating procedures. However, illegal fees are still found, especially with regard to education and health services. According to the report of Ombudsman, approximately $65 \%$ of complaints were not processed by institutions which received the complaints. The total number of complaints settled according to the data of the government secretariat of Makassar city from 2006-2011 fluctuates between $69-95 \%$ as released in a seminar on public services (Fig. 1).

Research questions: Based on the discussion, the research questions addressed in this study are:

- How is the standard operating procedure of public complaint handling implemented in the Makassar government secretariat?

- What are the factors affecting the settlement of public complaints in the Makassar government secretariat?

Complaint behavior is an important phenomenon due to its implication for the public perceptions. Furthermore, public complaints reflect the disatisfaction of the public related to the quality of services which they receive. It generates public demands including bureaucracy. According to the Decree of the Ministry for State Apparatus Reform No. 118 year 2004 on public complaint handling, public complaint is community monitoring done by the community, both spoken and written for government apparatus in the forms of constructive thoughts, suggestions, ideas and complaints.

Research by American Marketing Association (Kotler and Keller, 2012) investigated methods for measuring customer satisfaction, particularly the suggestion and complaint handling system, customer loss analysis and customer satisfaction survey. The measurement of customer satisfaction includes the suggestion and complaint system which is the responsibility of the government commonly known as public accountability. Kotler and Armstrong (2008) stated that marketing is a process which creates values for customers and builds a strong relationship with the customers in order to obtain particular values from the customers.

Complaints are customer's way to express dissatisfaction, although, not all dissatisfied individuals will complain. Dissatisfied individuals might not complain if they believe that complaining is not effective has low expected results/benefits or the cost for complaining is too high (Devereux and Weisbrod, 2006). The complaining cost (also whistle blowing) includes the time needed for complaining, unpleasant treatments and retaliation from those reported.

Gore in Fountain (1999) asserts that effective, efficient and responsive governance for realizing reformation can be done by establising customer contact service (customer service). New Public Management (NPM) globally covers the custumer service theme under the name of Total Quality Management (TQM), since, the last two decades. The idea that the term 'citizens' should be replaced with 'customers' of public sector services provided by the government emerged (Fountain, 1999). Government institutions should require public managers to see clients as customers and provide services using an effective concept of management whose idea is drawn from private service companies which emphasize accurate monitoring.

In the USA, although, the government organizations are different from the private ones, all services are provided by the business service sector, except services related to health, finance, food service and accomodation and communication (Fountain, 1999). Government organizations are created by the public for the public and need to be accountable to it. Public service is service provided by the government for the public as a form of the government's responsibility.

The satisfaction of customers in the out of crisis condition can be measured by: doing importance 
performance analysis in which customers are asked to rank the service quality of an organization in terms of certain elements, conducting problem analysis where customers are required to disclose two main problems which they face in relation to the service quality of an organization and their suggestion for improvement; implementing directly reported satisfaction which directly measures the service quality felt by customers using the scales of satisfied not satisfied, neutral, satisfied and very satisfied; derived dissatisfaction which measures the expectation of customers toward certain attributes and services and the gap between the expectation and the valuation of the service received (Deming, 1982). With regard to complaint mechanism, Blackmore in Wibawa proposes that:

Complaints mechanisms constitute a vital component of the quality initiative manifest in the public sector reforms... representing an important conduit through which service users can articulate their views. Moreover, where there is a desire to develop a more consumer oriented public sector, the ability to complaint effectively is the only recourse to redress where choice and exit are denied through either dependence on a specific service or monopoly service provision.

A study by Sudrajat suggests that the strategies for improving the management of complaints include: the improvement of complaint management organization, merit system for staffs handling complaints, providing infrastructures and complaint management facilities, development of complaint handling data management and providing operational funding for complaint management. Running government administration is different from running a business organization. Government administration must be run as a democratic government.

Denhardt and Denhardt (2007) describes seven key principles in new public service including serve citizens, not customers; seeks the public interest; value citizenship over entrepreneurship; think strategically, act democratically; recognize that accountability is not simple; serve rather than steer; productivity. The paradigm of new public service treats users of public services as citizens not as customers.

The report of public complaint management in BAPPENAS' public service outlines that the management of public complaints consists of four aspects: basic principles which comprise 4 elements:

- The first element is the answer to the question 'to whom we serve?

- Controlling the sources and inflows/channels of complaints

- Controlling institutional responses

- Basic attitude in receiving complaints

Complaint handling element, consisting of the following aspects:
- Sources of complaints

- Contents of complaints

- Complaint handling unit

- Complaint responses

- Feedback

- Complaint handling reports

Forms of reports: Channels of complaints, consisting of:

- Internal channel

- External channel

Hirschman (1970) in his research "exit, voice and loyalty" explains two mechanisms which can be chosen by customers dissatisfied with the quality of services provided by service providers; they can move (exit) to other service providers or file complaints (voice) with regard to the services or be loyal (loyalty) because they are satisfied with the government services. According to citizen's charter, there are 6 principles of public service which have to be obeyed by government officials (apparatus): standards, information and openness, choice and consultation, courtesy and standards, putting things right, value for money.

Although, there is are no specific guidelines on complaint handling for charity in Scotland, Skotlandia Public Service Ombudsman (SPSO) has provided guidance of complaint handling for public services which might be relevant to charity (Wallace, 2008). SPSO outlines that the complaint process must contain the following aspects:

- Access: clean, free, easy to understand and available to all

- Transparent: impartial, independent and can be audited

- Simple: some of the steps needed should be well documented

- Based on evidence: driven by facts and not assumptions

- Respect: appreciate complaints and rapporteur/ informants while managing any unacceptable behavior

- Authoritative: credible, consistent and definitive with authority

- Based on standards: quality, timeliness and effective communication

- Proportional: flexible in terms of methods and in accordance with the conditions

- Provable: reporting, open to feedback and used to drive improvements 
The Soc. Sci., 14 (11): 392-398, 2019

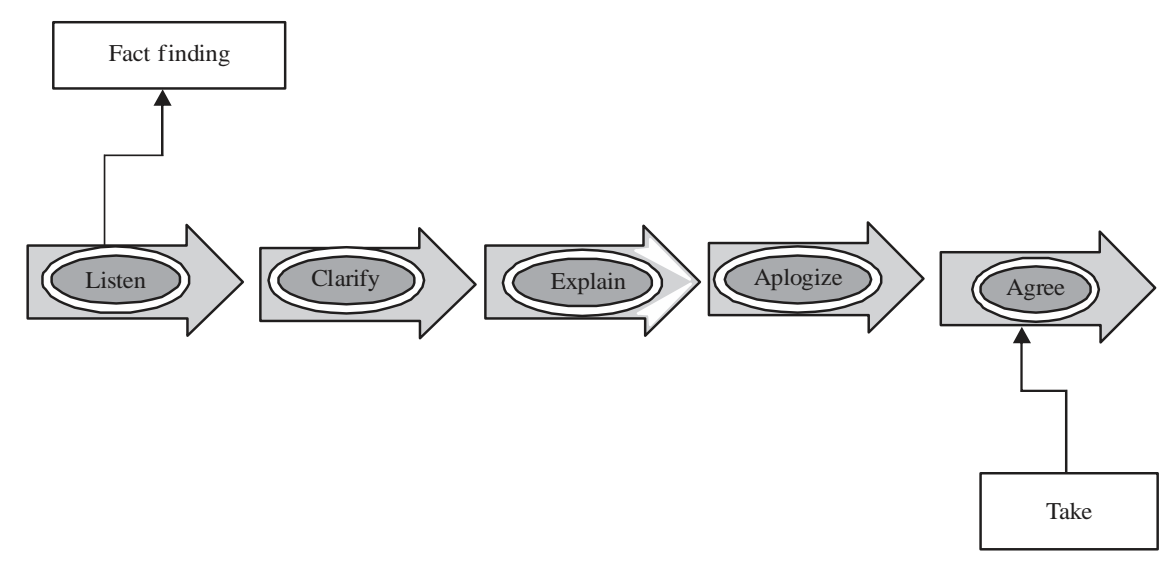

Fig. 2: Complaint process

From the academic perspective, Johnston (2001) describes good complaint process: having a clear procedure giving quick responses; reliability (consistency) of responses having one contact for complainants; ease of process use; maintaining the confidentiality of reporters; staffs understanding the complaining process; complaints are considered seriously; employees are empowered to handle the situation and having a follow-up procedure to check with the customer after the resolution.

In handling customer complaints, some steps have to be implemented prior to taking appropriate actions. According to Handayani in Sudradjat et al. (2014), the following steps should be taken when receiving complaints: Fig. 2 describes the complaint process which consists of the following stages:

- Listen: when receiving complaints, we have to listen calmly and sympathetically

- Clarify: if required, repeat the facts presented by customers

- Explain: after clarifying the problems, explain the root cause and what can be done to solve the problems

- Apologize: always apologize to customers if problems are related to company internal activities and disapointing customers

- Agree: prior to moving to the next stage, the approval of customers is required

- Take actions: applying solutions in accordance with what has been agreed by customers based on company policies

Levine et al. (1990) proposes three concepts which can be used to measure the performance of public organizations: responsiveness, the capability of public organizations in achieving their vision and organizational objectives; responsibility, the activities of public organizations are conducted based on the appropriate administration principles according to organization policies, both explicitely and implicitly. The measurement of responsibility is based on the analyses of documents and organization activity reports and accountability how policies and public organization activities obey political leaders/officials chosen by the public. The measurement of accountability is from the representatives, political officials/leaders and the public.

The assessment of government apparatu's performance can be done externally by obtaining public satisfaction responses. Thus, the government released an assessment instrument to measure the performance of public services externally through Ministry Decree No. 25/Kep/Menpan/2/2004 on the general guide for the construction of public satisfaction index for government institutions with the following indicators: service prochedure which refers to the simplicity of the service process, service requirements which refers to technical and administrative requirements, service officers (name, positions, authority and responsibilities), the officer's discipline which refers to the consistency of working hours based on particular policies or rules applied, the responsibilities of officers which refer to their authority and responsibilities, the officer's capability which refers to the skills and capabilities of the officers, service quickness which refers to the time target the service can be provided, fairness which refers to services for all individuals, politeness which refers to the behaviours and attitude of the officers, cost affordability which refers to the ability of the public to pay the service cost, cost standard which refers to the fee paid and the cost stated, service schedule which refers to the implementation of the service compared to the applied rules, environment which refers to clean and tidy facilities, safety which refers to the safety aspect in units delivering the services.

SOP is a document which contains written instructions on various administrations, it deals with how to do certain tasks or works, time, place and actors in 
The Soc. Sci., 14 (11): 392-398, 2019

\begin{tabular}{|c|c|c|c|c|c|c|c|c|}
\hline & & Excutant & & & \begin{tabular}{|l|} 
Quality \\
\end{tabular} & & & \\
\hline No. & Description & $\begin{array}{c}\text { Related } \\
\text { heads of } \\
\text { units }\end{array}$ & $\begin{array}{c}\text { Head of } \\
\text { complaint } \\
\text { handling } \\
\text { unit }\end{array}$ & $\begin{array}{l}\text { Staff of } \\
\text { complaint } \\
\text { handling } \\
\text { unit }\end{array}$ & $\begin{array}{c}\text { Required } \\
\text { documents }\end{array}$ & Time & Output & \\
\hline 1 & 2 & 3 & 4 & 5 & 6 & 7 & 8 & 9 \\
\hline 1 & $\begin{array}{l}\text { Receiving } \\
\text { Complaints }\end{array}$ & & & Start & $\begin{array}{ll}- & \text { Forms } \\
\text { - } & \text { Agenda }\end{array}$ & & & \\
\hline 2 & $\begin{array}{l}\text { Verifying the } \\
\text { complaints by } \\
\text { coordinating with } \\
\text { related unit }\end{array}$ & $\downarrow$ & & & Forms & & & \\
\hline 3 & $\begin{array}{l}\text { Follow up of } \\
\text { complaints; } \\
\text { providing answer } \\
\text { or direct actions }\end{array}$ & & $\downarrow$ & & Forms & & & \\
\hline 4 & Monitoring & & Done & & Forms & & & \\
\hline
\end{tabular}

Fig. 3: SOP in complaint handling unit, the city government of Makassar; complaint handling unit, Makassar government, 2012



Fig. 4: Framework

various activities. The following table describes the SOP in the public complaint handling unit, the city secretariate of Makassar, No. SOP-SDKM-HMS-02, dated 27 March, 2012, based on the Decress of Makassar Mayor No. 22, year 2009 on the job descriptions of structural positions in the secretariate of Makassar city government (Fig. 3 and 4).

\section{MATERIALS AND METHODS}

The research setting is the complain handing unit, the secretariate of Makassar city government. The implementation of SOP in the unit is still weak. The research employs qualitative method. According to qualitative research aims to understand a phenomenon experienced by research subjects such as behaviour, perception, motivation and action. This research aims to capture the social reality; it explores data related to values, emotions and feelings.
This research employs a case study approach at the level of complaint service organization, the city secretariate of Makassar. A case study is an approach to examine, explain or interpret a case in a natural context without any intervention from other subjects or parties. The focus of a case study is to highlight a decision or a set of decisions. Bogdan and Taylor assert that qualitative method is a research procedure which generates descriptive data in the form of written or spoken words from the observed subjects.

In general, this research uses both primary and secondary data. The main data are secondary data which include documents or written reports such as laws, rules and ministry decree. Besides that, it also employs primary data obtained from in-depth interviews with participants which were purposefully selected. The informants were individuals regarded as having knowledge of public complaint management. The key informants of this study were seven individuals who have knowledge of 
The Soc. Sci., 14 (11): 392-398, 2019

the implementation of SOP-SDKM-HMS-02, dated 27 Maret, 2012 and two individuals as trianggulators.

\section{RESULTS AND DISCUSSION}

Based on the presence data, the human resources of complaint handling unit of the Makassar city secretariate consist of 13 individuals, comprising 12 staffs and 1 head. From the 13 individuals, 2 individuals (15.4\%) were grade 3 staffs, 11 individuals were casual staffs (84.6\%). The unit still depends on the casual staffs for its daily operational and particularly for handling complaints. This results in some weaknesses because the casual staffs did not have full responsibilities, it becomes risky as the unit requires experienced and training individuals.

In general, SOP No. 02/SOP-Adm/HM/IX/2012 could not fully be used as a guideline as it has not covered the time periods of activities/stages which become references indicating the completion of complaints. Public complaints can be solved in a short time, although, sometimes the follow up activities of the complaints require a long time. It is expected that with the completion period, completion stages including administration and follow up activities, refer to the SOP as a guideline.

In terms of structure, the complaint handling unit is under the public relations unit. The head of the complaint handling unit is at echelon four, under the head of the public relations unit, that is at echelon three. Meanwhile, most units which become the objects of public complaints are at echelon two. There are conflicts of interest if an echelon four official monitors and supervises the implementation of follow up activities which are the responsibilities of an echelon two official.

General description of complaint handling at the secretariate of Makassar city: Figure 5 indicates that most public complaints are from printed media (newspapers) which reach more than $90 \%$. Meanwhile, complaints through telephone, SMS, email, letters and direct complaints are only $10 \%$. This suggests that the public is still reluctant to file complaints directly; they prefer to file complaints through mass media. This might be related to the difficulties in understanding the complaint procedures and the safety of complainants after filing complaints. The implementation of complaint handling SOP at the secretariate of Makassar city.

Reception and registration of complaints: Reception and registration of complaints by staffs who have been assigned based on SOP; however because of the lack of human resource's understanding, the implementation of SOP is often not effective. This is related to the distribution of tasks in terms of reception and registration of complaints and the requirements of staff's skills and competence in relation to complaint reception and registration.



Fig. 5: Recapitulation of complaint handling from January-August, 2015

Verification of complaints: SOP No. 02/SOPAdm/HM/IX/2012 gives a task to the head of complaint handling unit to conduct an internal mechanism in verification of complaints which has been applied according to the SOP. Based on the verification, the head then classifies the complaint reports based on the authority of units, implements certain strategies if the complaints involve some units and if the complaints are related to cases reported by media.

Coordination: Next, the head of complaint handling unit forwards the complaints to related units. The head is expected to coordinate the complaints with related units and implement particular strategies if the complaints filed are not addressed by the units.

Follow-up: The follow-up actions become the responsibility of related units. The complaint handling unit waits for the response. The follow-up of complaints has not been based on the SOP. The follow-up actions taken by related units can be done by the units themselves or involve the complaint handling unit directly or through mass media.

Monitoring of follow-up actions: The head of complaint handling unit conducts monitoring of follow-up actions done by related units. This role has not been based on the SOP. The head directly visits the site reported and applies reward and punishment to the follow-up actions.

\section{CONCLUSION}

It is suggested that the implementation of SOP No. 02/SOP-Adm/HM/IX/2012 in the complaint handling unit, the secretariate of Makassar city, should be improved in terms of its coordination, follow-up actions and monitoring. Every stage of follow-up actions should be communicated with complainants, so that, the complainants know that their complaints are addressed. Furthermore, the SOP should be improved. It should 
include the period of complaint handling (the completion). The improvement should also include the quality improvement of human resources through staff selection, giving appropriate salary and giving education and training related to public services. Last, the position of officials responsible for complaint handling should be raised to echelon two, equal to most of heads of units which become the objects of public complaints.

\section{REFERENCES}

Deming, W.E., 1982. Quality, Productivity and Competitive Position. Massachusetts Institute of Technology, Cambridge, UK., ISBN: 9780911379006, Pages: 373.

Denhardt, J.V. and R.B. Denhardt, 2007. The New Public Service: Serving, not Steering. ME Sharpe. New York, USA., Pages: 728.

Devereux, P.J. and B.A. Weisbrod, 2006. Does satisfaction with local public services affect complaints (voice) and geographic mobility (exit)?. Publ. Finance Rev., 34: 123-147.

Fountain, J.E., 1999. Paradoxes of public sector customer service. Master Thesis, John F. Kennedy School of Government, Harvard University, Boston, Massachusetts.

Hirschman, A.O., 1970. Exit, Voice and Loyalty: Responses to Decline in Firms, Organizations and States. 2nd Edn., Harvard University Press, Cambridge, MA., USA., ISBN-13: 9780674276604, Pages: 162.
Johnston, R., 2001. Linking complaint management to profit. Intl. J. Serv. Ind. Manage., 12: 60-69.

Kennedy, J.F., 2010. From Reformasi to Institutional Transformation: A Strategic Assessment of Indonesia's Prospects for Growth, Equity and Democratic Governance. Harvard Kennedy School, Ash Center for Democratic Governance and Innovation, Cambridge, Massachusetts, Pages: 111.

Kotler, P. and G. Armstrong, 2008. [Marketing Principles]. 12th Edn., Erlangga Group, Jakarta, Indonesia, (In Indonesian).

Kotler, P.T. and K.L. Keller, 2012. Marketing Management. 14th Edn., Pearson, New Jersey.

Levine, C.H., B.G. Peters and F.J. Thompson, 1990. Public Administration: Challenges, Choices, Consequences. Scott Foresman \& Company, Illionis, USA., ISBN-13: 978-0673399977, Pages: 474.

Sudradjat, A.S., G.K. Kumara and N. Susandi, 2014. Complaint handling and service recovery analysis at low cost carrier airline and effects on customer satisfaction in Indonesia. Int. J. Sci. Res. (IJSR.), 3: 181-186.

Synnerstrom, S., 2007. The Civil Service: Towards Efficiency, Effectiveness and Honesty. In: Indonesia: Democracy and the Promise of Good Governance, McLeod, R.H. and A.J. MacIntyre (Eds.). Institute of Southeast Asian Studies, Singapore, ISBN-13: 978-9812304599, pp: 159-77.

Wallace, J., 2008. Complaint in the charity sector. Scottish Consumer Council, UK. 